\title{
Failure to Take Reasonable Environmental Measures as a Breach of Investment Treaty?
}

Peter A Allardv The Government of Barbados, PCA Case No 2012-o6, Award, 27June 2016 (Gavan Griffith, Andrew Newcombe, Michael Reisman)

\author{
Joshua Paine
}

Max Planck Institute Luxembourg for International, European and Regulatory

Procedural Law, Luxembourg

josh.painer@gmail.com

\section{Keywords}

environment - expert evidence - harm - loss - damage - proof - definition of investment - full protection and security

Arbitral tribunals constituted under investment treaties have in recent years been the most active site for the adjudication of international law disputes with an environmental or natural resources component. ${ }^{1}$ Many cases have concerned claims by an investor regarding the host state's refusal of a permit for the investor's project on purportedly environmental grounds, ${ }^{2}$ or

1 See generally Jorge Viñuales, 'Foreign Investment and the Environment in International Law: The Current State of Play' in Kate Miles (ed), Research Handbook on Environment and Investment Law (Edward Elgar, forthcoming) <http://papers.ssrn.com/sol3/papers .cfm?abstract_id=2661970 $>$ accessed 1 April 2017 (noting in a recent survey which is not exhaustive some 114 investor-state disputes with an environmental component, more than half of which were filed since the year 2012, and all but 12 of which were filed since the year 2000); Daniel Behn and Malcolm Langford, 'Trumping the Environment? An Empirical Perspective on the Legitimacy of Investment Treaty Arbitration' (2017) 18(1) JWIT 14, 17-19 (utilising a narrower definition of environmental cases, resulting in a dataset of 49 concluded cases as at 1 October 2016).

2 See eg William Ralph Clayton, William Richard Clayton, Douglas Clayton, Daniel Clayton and Bilcon of Delaware, Inc v Canada, PCA Case No 2009-04, Award on Jurisdiction and Liability (17 March 2015); Crystallex International Corp v Bolivarian Republic of Venezuela, ICSID Case No ARB(AF)/11/2, Award (4 April 2016). 
environmental regulation of products produced by an investor. ${ }^{3}$ The Award in Allard $v$ Barbados, rendered on 27 June 2016, is striking because the Tribunal determined the merits of a claim by the investor, Mr Allard, that the host state's failure to take reasonable environmental measures destroyed the value of his eco-tourism attraction and accordingly violated several investment treaty standards.

Ultimately, the Tribunal concluded after a thorough examination of competing expert evidence that Mr Allard had not proved that any environmental degradation had occurred in the period between his initial investment in the eco-tourism attraction and his decision to close it. Furthermore, even assuming arguendo damage could be shown, the Tribunal found any such damage could not be attributed to Barbados' conduct. On the contrary, Barbados was found to have taken reasonable measures to protect the investor's environmental sanctuary. Thus a claim for breach of the full protection and security standard, which had drawn for interpretive guidance on Barbados' obligations under environmental treaties, was dismissed.

Overall the Award is significant in highlighting that in investment arbitration, as in other areas of international adjudication, environmental cases require tribunals to evaluate detailed and often conflicting expert evidence on scientific and technical matters, and proving environmental harm remains difficult. The Award raises the possibility that, as a matter of principle, a state could violate its investment treaty obligations through a failure to take sufficient environmental measures, although such cases are likely to remain rare. The Award also highlights that investment treaty arbitration is focused on providing a remedy for investors who have suffered damage as a result of a breach by the host state of investment treaty obligations. Furthermore, claimants with non-commercial motivations may fail to qualify as having a covered investment, depending on the definition of investments within the relevant investment treaty. Thus investment treaty arbitration is unlikely to enable environmentally conscious investors to bring claims with an erga omnes aspect.

The case concerns Mr Allard's investment in the Graeme Hall Nature Sanctuary (the Sanctuary), located within a wider area of wetlands, the Graeme Hall Swamp. Between 1996 and 1999, Mr Allard acquired the land compromising the Sanctuary with the intention of developing an eco-tourism attraction.

3 See eg Chemtura Corporation (formerly Crompton Corporation) v Canada, UNCITRAL/ NAFTA, Award (2 August 2010). 
The Sanctuary consists of a mangrove forest and various wetlands which are connected to the ocean by a canal. The Claimant's essential case was that Barbados' improper operation of a 'Sluice Gate' at the end of the canal connecting the Sanctuary to the ocean had caused the Sanctuary to turn into a freshwater system, leading to numerous types of environmental degradation and rendering the investment worthless for the purposes of operating an ecotourism attraction (paras 3, 55-61). On this basis the Claimant alleged violations of the obligations in the Canada-Barbados BIT to accord his investment fair and equitable treatment (FET), full protection and security (FPS), and not to expropriate the investment except on the specified conditions. ${ }^{4}$

In contesting these claims, Barbados' essential positon was that the Sanctuary had not suffered any material environmental degradation between Mr Allard's initial decision to invest and the Sanctuary's closure in 2009, which was due to the attraction not being commercially viable. In the alternative, Barbados contended that any environmental degradation which had occurred was not due to its conduct, as it had taken appropriate steps for environmental protection of the Sanctuary. Thus the Tribunal had to determine a key factual disagreement over whether the Sanctuary had suffered environmental degradation, sufficient to render its operation as an eco-tourism attraction impossible, in the 'Relevant Period' between 1996, when Mr Allard initially invested, and 2009, when the Sanctuary closed (paras 84-85). To the extent that any damage was established, the Tribunal also had to determine whether such damage was due to Barbados' conduct.

As is standard in environmental disputes, in determining whether environmental degradation had occurred the Tribunal faced competing, highly detailed expert evidence led by the Parties in relation to multiple technical parameters. Overall, the Claimant failed to prove any of the alleged forms of environmental degradation had occurred in the Relevant Period. In relation to the claimed decline in water salinity, which can harm mangrove-based ecosystems, the Tribunal found on the data before it that while salinity had declined in the total period in which data was available (1986-2015), the Claimant had not proved that this change occurred during the Relevant Period (1996-2009) (paras 88-102). Having benefited from the evidence of the Parties' expert witnesses, and clarification of their points of methodological disagreement, the Tribunal further concluded that the Claimant had not discharged his burden

4 Agreement between the Government of Canada and the Government of Barbados for the Reciprocal Promotion and Protection of Investments (signed 29 May 1996, entered into force 17 January 1997) (Canada-Barbados BIT) <http://investmentpolicyhub.unctad.org/ Download/TreatyFile/280 > accessed 1 April 2017. 
of proof in relation to any of the other alleged forms of environmental damage, namely declines in water quality other than salinity; mangrove health; diversity of fish and bird species; and health of crabs (paras 112-138). The Tribunal emphasised that the Claimant's experts accepted that any damage to mangrove health was a potential future harm rather than a realized harm (para 115).

In short, the Claimant failed at the first hurdle of establishing that loss or damage had been suffered, in the form of the types of environmental degradation that were said to have forced the closure of the Sanctuary (paras 139140). Nevertheless, for the sake of completeness, the Tribunal dealt with the related threshold question of whether the asserted environmental damage had been caused by Barbados. The key issue here was whether Barbados' failure to properly operate the Sluice Gate - which, according to the Claimant, would allow seawater to enter the Sanctuary - had caused the decline in water salinity. Evaluating the differing theories of the Parties' experts, and the broader evidentiary record, the Tribunal concluded that the Claimant had not proved that the operation of the Sluice Gate was a significant factor in maintaining the salinity of the Sanctuary, such that its mismanagement could have caused the decline in salinity (paras 157-164). Accordingly, the Tribunal concluded at this point that even if it were to find Barbados had breached any of its BIT obligations, the Claimant had not established any loss or damage to his investment resulting from Barbados' conduct. Nevertheless, given the Parties' extensive argumentation the Tribunal addressed the alleged BIT violations (paras 167-168).

The Claimant's FET claim was based on a series of representations that were said to create a legitimate expectation that Barbados would generally uphold its environmental policies in relation to the protection of the Sanctuary and adequately operate the Sluice Gate (paras $172-176$ ). The Tribunal found that none of the statements relied upon could give rise to a legitimate expectation that Barbados would take specific steps for the environmental protection of the Sanctuary. For example, a planning instrument was a general policy document which was subject to change (para 200). A feasibility study commissioned by Barbados, and performed by external consultants, prior to the approval of the Claimant's project, was not attributable to Barbados. It was simply a recommendation for the government to consider during its decisionmaking process (paras 205-206). Significantly, the Tribunal found that Barbados' approval of the Claimant's environmental management plan merely entitled the Claimant to proceed with the project without objection from the state on environmental grounds. The approval did not constitute an affirmative representation that Barbados would manage the Sluice Gate as proposed in the Claimant's environmental plan (paras 213-216). Furthermore and crucially, 
the Tribunal found that the Claimant had not relied on any representations made by Barbados in taking any of his investment decisions. Rather, Mr Allard presented as 'a person of philanthropic intentions and of enthusiasms' whose decisions to invest were not made in reliance on any general expressions of environmental policy by Barbados or specific representations regarding operation of the Sluice Gate (paras 220-223).

The other key BIT claim made by the Claimant was that Barbados had violated the FPS standard by failing to take reasonable environmental measures to protect the Sanctuary. The Claimant suggested a series of 'reasonable measures' that Barbados should have taken, and contended that Barbados' obligations under the Convention on Biological Diversity ${ }^{5}$ and the Ramsar Convention ${ }^{6}$ heightened the level of diligence required (paras 230-234). Assessing the evidentiary record, the Tribunal found that the measures taken by Barbados to prevent environmental damage to the Sanctuary fulfilled the due diligence standard required by the FPS obligation. The Tribunal emphasised that the issues surrounding the Sluice Gate involved a wide range of stakeholders, beyond the investor, as they impacted the hydrology of a wider area (paras $245^{-250}$ ). The FPS obligation was limited to taking reasonable action and did not require the host state to take specific steps which an investor asked of it. Furthermore, Barbados' obligations under other environmental treaties did not change the FPS standard but could 'be relevant in the application of the standard to particular circumstances' (para 244).

The Claimant also contended that his ability to run an eco-tourism business, the only permitted use for the Sanctuary, had been indirectly expropriated by Barbados' conduct (paras 254-256). The Tribunal held that that a substantial deprivation of property, as required for an indirect expropriation, had not occurred, as Mr Allard remained the owner of the Sanctuary, where he continued to operate a café business (paras 263-264).

At the end of the merits hearing Barbados' also raised two noteworthy jurisdictional objections given Mr Allard's answers under cross-examination. First,

5 Convention on Biological Diversity (opened for signature 5 June 1992, entered into force 29 December 1993) 1760 UNTS 79.

6 Convention on Wetlands of International Importance especially as Waterfowl Habitat (opened for signature 2 February 1971, entered into force 21 December 1975) 996 UNTS 245 (Ramsar Convention). As part of acceding to the Ramsar Convention in 2006, Barbados designated the wider Graeme Hall Swamp, in which the Claimant's sanctuary was located, as 'a wetland of international importance' as provided for in art 2 of the Ramsar Convention. See Ramsar Sites Information Service, List of Ramsar sites for Barbados <https://rsis.ramsar.org/ ris-search/?f[o]=regionCountry_en_ss\%3ABarbados\&pagetab=1 $>$ accessed 1 April 2017. 
Barbados' sought to have the Tribunal revisit its earlier Award on Jurisdiction regarding whether Mr Allard qualified as in investor. Specifically, the Award on Jurisdiction, rendered in June 2014 but made public in September 2016,7 had addressed the exclusion from the definition of investments in the relevant BIT of property 'not acquired in the expectation or used for the purpose of economic benefit or other business purposes.' ${ }^{8}$ The Tribunal found that Mr Allard had honestly held expectations of an eventual profit when establishing the Sanctuary, although these were 'secondary and in the background to his principal motivations of environmental and public purposes. ${ }^{9}$ The treaty clause in the Canada-Barbados BIT did not require comparison to the return a disinterested investor might seek, and Mr Allard's expectation of some return on the monies committed meant the exclusion was not made out. ${ }^{10}$ At the merits phase the Tribunal held that Mr Allard's answers under cross-examination did not warrant revisiting the prior finding that Mr Allard 'was successful, if only just' in qualifying as investor, which would in any case potentially be res judicata (paras 272-275). The second late jurisdictional objection raised by Barbados was that Mr Allard had admitted under cross-examination that his claims were for future harm, and it was a requirement of jurisdiction under the BIT that an investor had suffered actual loss or damage. The Tribunal did not consider this issue, reasoning that this objection was not based on any new fact and thus should have been raised during the hearing on jurisdiction (paras 276-277).

While the Claimant was ordered to bear the costs of the arbitration and of Barbados, the Tribunal capped Barbados' claimed legal costs of almost 5.2 million USD at 2.25 million USD, having regard to the issues of proportionality with the amount in dispute, and disparity with the Claimant's legal costs (paras 295-315).

The Allard award is a particularly stark example of the substantial involvement of investment treaty tribunals in adjudicating disputes with an environmental component, albeit with a focus on liability under investment treaties, reflecting their confined jurisdiction. As with claims concerning environmental

Peter A Allard $v$ The Government of Barbados, PCA Case No 2012-06, UNCITRAL, Award on Jurisdiction (13 June 2014).

8 Canada-Barbados BIT (n 4), art 1 (f).

$9 \quad$ Allard $v$ Barbados, Award on Jurisdiction (n 7) para 51. See also ibid paras 49-50.

$10 \quad$ ibid para 52. 
harm in recent interstate adjudication, in investor-state arbitration such cases require adjudicators to understand and evaluate detailed, typically conflicting expert evidence on scientific and technical matters. ${ }^{11}$ The Allard tribunal showed a strong capacity to engage with partially conflicting expert evidence and, with the benefit of this information, to evaluate the evidentiary support for the Parties' contentions. The case also highlights the difficulties of proving environmental harm and causation in international adjudication. As noted, while the Claimant was able to establish a significant decline in salinity in the total period during which data was available, he was unable to prove that this occurred during the Relevant Period between when he first invested in 1996, and when the sanctuary closed, in 2009 .

Parts of the Claimant's evidence, which did not convince the Tribunal, suffered from significant methodological shortcomings. For example, the Claimant's case regarding the alleged decline in the number of fish and bird species relied to a significant degree on observation by an employee who took frequent walks through the Sanctuary (paras 119-121, 127-133). In this respect, Allard might be contrasted with other investment treaty cases where host states, as respondents, have prevailed after producing stronger evidence supporting the technical appropriateness of challenged environmental or public health measures. ${ }^{12}$ Potentially, the typical task for respondent host states, of justifying an environmental measure as a reasonable regulatory response to an environmental risk, is also less challenging than the Claimant's formidable challenge in this case of affirmatively proving that environmental harm had occurred and was caused by Barbados.

The Allard award is also notable in raising the issue of whether a host state's failure to take sufficient environmental measures might constitute a breach of investment treaty obligations. As noted above, the Tribunal held that Barbados' obligations under environmental treaties did not change the content of the FPS standard but could be relevant in applying the standard to particular cases.

11 For recent examples of interstate adjudication where tribunals have engaged with detailed scientific evidence concerning environmental harm see Certain Activities carried out by Nicaragua in the Border Area (Costa Rica v Nicaragua) and Construction of a Road in Costa Rica along the San Juan River (Nicaragua v Costa Rica), International Court of Justice Judgment (16 December 2015) unpublished; Pulp Mills on the River Uruguay (Argentina $v$ Uruguay) (Judgment) [2010] ICJ Rep 14; Republic of the Philippines $v$ People's Republic of China, UNCLOS Arbitral Tribunal, PCA Case No 2013-19, Award (12 July 2016).

12 Consider in this regard Chemtura (n 3) paras 135-143, 153-4; Methanex Corp $v$ United States of America, UNCITRAL/NAFTA, Final Award (3 August 2005) pt III, ch A, paras 101-2; Philip Morris Brands Sàrl, Philip Morris Products SA \& Abal Hermanos SA v Oriental Republic of Uruguay, ICSID Case No ARB/10/7, Award (8 July 2016) paras 391-396. 
Some types of investments, such as those whose value depends on their physical state, will clearly be liable to being damaged if the host state is not sufficiently diligent as an environmental regulator. Yet the Award makes clear that the FPS standard does not require host states to take specific steps demanded by an investor, thus recognising that regulators often face polycentric problems, impacting a wider range of interests than the concerns of a specific investor.

The Tribunal's application of the FET standard suggests that while it may be possible for legitimate expectations to arise regarding the future state of environmental regulation, such expectations must arise from specific representations. General planning policies, feasibility studies carried out prior to the approval of a project, and the approval of an investor's environmental impact assessment, will not give rise to expectations regarding specific conduct by the host state. The Tribunal did not address the Claimant's argument that Barbados' obligations under environmental treaties confirmed the reasonableness of his expectations, having found that no specific representations giving rise to reasonably held expectations were given (paras 177-178, 208). By themselves a state's international environmental obligations are likely to be too general to create expectations regarding a specific course of conduct by the host state. That said, in some awards where investors have challenged regulation enacted on environmental or public health grounds tribunals have noted a pattern of tightening international and domestic regulation as relevant to determining the legitimate expectations of affected investors. ${ }^{13}$

The Allard award also foregrounds the issue of whether suffering loss or damage is a pre-requisite to a successful investment treaty claim. As noted, central to the Tribunal's reasoning was that the Claimant had not proved that he had suffered loss, in the form of alleged environmental damage, or that such loss was caused by Barbados' conduct. The Tribunal did not address Barbados' late jurisdictional objection regarding whether suffering loss was a condition of jurisdiction. The treaty language invoked by Barbados was from the clause providing for investor-state dispute settlement, which covered claims by an investor 'that a [Contracting Party's] measure ... is in breach of this Agreement and that the investor has incurred loss or damage by reason of, or arising out of, that breach.'14 It is unclear whether an investor-state tribunal would take the dramatic step of declining jurisdiction on the basis that an investor was not claiming to have suffered loss or damage. At least one tribunal has taken the view that in international investment law, because of the content of the

\footnotetext{
13 Philip Morris v Uruguay (n 12) para 430; Glamis Gold Ltd v United States of America, UNCITRAL/NAFTA, Award (8 June 2009) para 767.

14 Canada-Barbados BIT (n 4), art 13(1).
} 
relevant primary rules, international responsibility can only arise from acts which cause damage. ${ }^{15}$ Other tribunals have found breaches of investment treaties even where claimants have failed to prove that loss was suffered ${ }^{16}$ or that any loss was caused by the relevant wrongful act. ${ }^{17}$ Barbados' argument that the incurring of loss was a prerequisite to jurisdiction under the relevant treaty provision was certainly plausible. However, in practice investors will nearly always claim that some of form of loss has been suffered, meaning the question of loss will be more relevant at a merits stage, and specifically in awarding appropriate relief, than as a question of jurisdiction. ${ }^{18}$

Finally, the Tribunal's determination that Mr Allard qualified as investor, despite his primary objectives being philanthropic rather than commercial, reflects a careful application of the treaty language concerning the definition of an investment, combined with the Tribunal's evaluation of the underlying factual realities. As the Tribunal noted, under the relevant treaty, the exclusion from covered investments could not, given its terms, be made out if there was any expectation, at the time of investing, of an economic benefit, even if this was not the Claimant's primary motivation. ${ }^{19}$ Thus this was not a true case

15 Merrill \& Ring Forestry LP v Canada, ICSID Case No UNCT/07/1, Award (31 March 2010) paras 244-245, 266.

16 The Rompetrol Group NVv Romania, ICSID Case No ARB/o6/3, Award (6 May 2013) paras 277-294, 299 (finding a breach of the FET standard in one minor respect but holding that the claimant had not discharged its burden of proving that it had suffered economic loss or damage resulting from the breach).

17 Biwater Gauff (Tanzania) Ltd $v$ United Republic of Tanzania, ICSID Case No ARB/05/22, Award (24 July 2008) paras 786-807 (holding that various breaches of an investment treaty had occurred but the investor had failed to prove a causal link between the wrongful conduct and the claimed losses). Arbitrator Born, partially dissenting in Biwater Gauff, saw the issue as one of quantification of damages rather than causation. He held that the relevant investment treaty breaches had caused injury to the claimant, but the evidence failed to show there was any monetary value associated with this injury; ibid, Concurring and Dissenting Opinion of Arbitrator Born, paras 15-29.

18 For example, in the Methanex case, the tribunal quickly rejected the United States' challenge to jurisdiction based on the argument that the alleged treaty breach was not the proximate cause of the alleged loss and thus the claimant had not 'incurred loss or damage by reason of or arising out of' the alleged breach, as required by art 1116(1) of the North American Free Trade Agreement (signed 17 December 1992, entered into force 1 January 1994) 32 ILM 296. For the tribunal, at the jurisdictional stage the claimant only needed to claim, rather than prove, that it had suffered loss or damage. Furthermore, the issue was intertwined with the merits and thus appropriate to decide at that stage: see Methanex (n 12) Partial Award (7 August 2002) para 86.

19 See above text at nn 8-10. 
of a not-for-profit actor qualifying as an investor, a prospect which is possible under some investment treaties, ${ }^{20}$ depending upon the particular definition of an investment. Notably, the Tribunal did not apply any additional criteria, beyond the definition of an investment in the Canada-Barbados BIT, regarding this aspect of subject-matter jurisdiction. Some tribunals constituted under the ICSID Convention - which conditions the Centre's jurisdiction on disputes 'arising directly out of an investment' ${ }^{21}$ - and non-ICSID tribunals, have imposed additional requirements for the existence of an investment, beyond the terms of the relevant treaty. Such additional criteria could serve to exclude non-commercial activities. ${ }^{22}$ Allard makes a minor contribution in this area by suggesting that an investor having mixed philanthropic and commercial motives might still qualify under investment treaties that limit the definition of an investment to activities conducted with the purpose of economic benefit.

20 See eg Agreement between the Slovak Republic and the Islamic Republic of Iran for the Promotion and Reciprocal Protection of Investments (signed 19 January 2016, not yet in force) art $1(2)<$ http://investmentpolicyhub.unctad.org/Download/TreatyFile/36o1> accessed 1 April 2017.

21 Convention on the Settlement of Investment Disputes between States and Nationals of Other States (opened for signature 18 March 1965, entered into force 14 October 1966) 575 UNTS 159, art 25(1).

22 See generally Nick Gallus and Luke Eric Peterson, 'International Investment Treaty Protection of NGOs' (2006) 22 Arb Int 527, 537-543. 